УДК 378. 1:811(7)

DOI: 10.36550/2415-7988-2020-1-188-174-179

\author{
ANTONIVSKA Maryna Oleksandrivna - \\ Lecturer, Foreign Languages Department \\ Kyiv National University of Culture and Arts, \\ ORCID:https://orcid.org/0000-0002-4451-3735 \\ e-mail: antonivska_maryna@ukr.net \\ SARNOVSKA Natalia Ivanivna- \\ Lecturer, Foreign Languages Department \\ Kyiv National University of Culture and Arts, \\ ORCID:https://orcid.org/0000-0001-7278-5183 \\ e-mail: nat_sarnovskaya@ukr.net
}

\title{
ICT USAGE FOR FOREIGN LANGUAGES STUDYING IN HIGHER EDUCATION ESTABLISHMENTS OF SOCIO-CULTURAL SPHERE
}

Formation and justification of the relevance of the problem. An important component of a democratic society under development in Ukraine is the focus on the humanistic values of world culture. The public, politicians, scientists, and educators are increasingly aware of the need to build a united Europe, in particular, a scientific and educational space without borders. Particular attention is paid to higher education, universities, institutions, their intellectual potential, which is constantly being strengthened and used in the European integration process, to disseminate the necessary knowledge to realize common values.

The current state of Ukraine's international relations in various spheres of life, its entry into the European and world space, new political, socio-economic and cultural realities require certain transformations in the sphere of education as an important state institution, including in the field of foreign language learning. Today, as never before, the status of a foreign language tends to grow steadily. It is increasingly becoming an intercultural communication medium within the international community. All this determines the main strategic directions for improving the goals, content, methods, techniques, and means of learning a foreign language.

According to the National Doctrine of Educational Development, the main directions of updating the content of higher education are the personal orientation of the education system, priority of human and national values, quality assurance of education based on the latest achievements of science, culture and social practice $[7$, p. 3$]$.

The state needs highly qualified specialists, professionals with foreign language knowledge who are capable of absorbing everything new and progressive, ready to generate and implement fresh original ideas, as well as to benefit from international cooperation and form a new attitude to Ukraine in Europe and the world. The demands of time and the radical reform of the education system in Ukraine orient the current and future teachers and lecturers to abandon the authoritarian style of teaching in favor of a humanistic approach, to apply methods that promote the development of creative foundations of the individual, taking into account the individual characteristics of participants in the educational process. The main means of human communication is language, and in multilingual space - several languages.

That is why the study of foreign languages acquires a special status in our country.

The rapid changes that are taking place in Ukrainian society, the modernization of the educational system, advances in the theory and practice of teaching foreign languages put before the Ukrainian education system the need to update the content and methods of applying innovative approaches to teaching a foreign language in a professional direction. In today's society, a clear social order is formed for the command of foreign languages. Ukraine's rapid entry into the world and European space creates a need for some changes in the field of education, and especially in the field of foreign language teaching in higher educational establishments.

Analysis of resent research and publications. Recent decades have been a watershed in foreign language teaching and studying processes at both secondary and high schools. This interrelation is quite logical since the student who comes to study has considerable experience in learning a foreign language and automatically transfers his or her expectations to the process and outcome of the university language training. Also important are the 
changes caused by the internationalization of the educational space, which were enlightened in the works of foreign (F. Altbach, M. Van der Wende, J. Davis, S. Cunningham, J. Knight, etc.) and Ukrainian scientists (M. Boychenko, S. Verbytska, K. Korsak, O. Lokshyna, L. Pukhovska, A. Sbruyev, etc.) A lot of scientific works deal with the question of implementation ICT in teaching and studying English language as a foreign (Dudeney, Wright, Hartoyo). Some scholars have noted that the widespread use of identified technologies can significantly increase the effectiveness of active learning methods to all forms of organization of educational process in the study of a foreign language, namely: practical, individual lessons, during independent work (Nadolskaya). Other scientists have considered the use of ICT as a means of increasing motivation, commitment to the systematic study of a foreign language, which allows toobtain quick results in learning a foreign language (Wheeler).

Several Ukrainian scholars, including L. Viktorov, Y. Polikarpov, O. Ponomaryov, Y. Rudnik and L. Shevchuk are devoted to innovative changes in foreign language training of students. Most authors see them as actively implementing information technology in the classroom and extra-curricular work. The vast majority of scientific works are devoted to the consideration of innovative changes in language education at an angle of change in approaches to communication, activity-oriented sphere, and real-life situations.

Today, preferences are given to higher education institutions, where teachers understand the psychological characteristics of the student audience, are guided in the modern achievements of pedagogical science and practice, have a variety of innovative methods and forms of learning that affect professionalcreative development and self-development of future specialists. Therefore, «the leading function in the design of learning technology belongs to the teacher, who, in accordance with the specific purpose of the learning process, requests and opportunities of learners, selects the content, forms and methods of learning, their sequence, time and stages of application, to achieve the planned guaranteed positive result»» [4, p. 28].

The purpose of the article is to evaluate the importance of information and communication technologies usage in studying foreign languages in higher education establishments and develop practical recommendations to enhance the effectiveness of foreign language studying using ICT, to consider and reveal for information and communication technologies foreign languages learning in higher education establishments as a coherent and integrative system, which provides, in accordance with the learning objectives, the most rational use of the selected principles of communicativeness, expediency of implementation and mutual complementation of interactive methods and techniques to achieve a pre-planned (desired) learning outcome.

The main material of the study. At the present stage of Ukrainian state formation and its close cooperation with many European countries, reforming the higher education system is a key element in the European integration process and opens new opportunities for Ukrainian youth.

The new socio-cultural reality has made the study of foreign languages one of the priorities for future professionals and, thus, necessitated the modernization of the modern higher education system. As the process of teaching and learning a foreign language is considered more complicated than similar processes in most other subjects, improving the efficiency and effectiveness of learning is a relevant topic for research.

According to the European Guidelines on Language Education, one of the strategic tasks of reforming the content of education in Ukraine is the development of national standards for foreign languages studying. Modern interactive technologies, innovative approaches, and methods of teaching and studying foreign languages are aimed at the development and self-improvement of the individual, to open up his reserve capabilities and creativity, create the prerequisites for effective improvement of the educational process in higher education.

According to the peculiarities of the educational process, the basic principles of modern methods of a foreign language teaching and studying in high school are movement from the whole to the individual, learner-centered lessons, classes' content, their focus on social interaction, learning intercultural features, professional orientation [1, p. 131].

Since the main purpose of modernizing the foreign language learning system in Ukraine is to use linguistic means to ensure a real communication process and to achieve their own communication goals, a characteristic tendency to enhance the communicative orientation of the educational process is formed.

Communication is the process of exchanging information (facts, ideas, views, emotions, etc.) between communicating 
individuals. Communicative situations used in foreign language learning should reproduce typical real life situations in the relevant field of communication. An important factor influencing the communication process is the organization of interaction (dialogue) between the communicating individuals, namely the interactive function of communication (exchange of actions). The importance of ICT, according to W. Veen, I. Lam, R. Taconis, lies in the fact that it provides educational dialogue, flexibility of the structure of knowledge representation and autonomy of learning activities.

It is known that there are the following models of foreign languages teaching organization in high school: passive - the student acts as a passive listener (lecturemonologue, demonstration, new material explanation); active - the student is an active subject of study. In an active model, foreign language learning can be implemented not interactively (independent work, exercises, creative tasks), or interactively, thus in the conditions of constant, active interaction (dialogue) of all learning subjects (pair work, discussion, conversation, frontal survey, etc.).

Information and communication technologies (ICT) are of key importance at all levels of the educational system. At each stage of cognitive activity, research and practical applications in all branches of knowledge ICT perform both the functions of tools and objects of knowledge. Consequently, ICT innovations not only provide a revolutionary development in this branch of knowledge, but also have a direct impact on the scientific and technological progress in all areas of society. Thus, information and communication technologies are a class of innovative technologies for the rapid accumulation of intellectual and economic potential of strategic resources, ensuring sustainable development of society. This paper discusses the opportunities of ICT, the ways of their realization in the Russian system of higher education training on an example of a discipline «Foreign language». Scientists have different approaches to the definition of ICT concepts. In the scientific literature can be found the following terminology: «IT training», «computer-based training technology», «new information technologies in education» or «NIT Education», «multimedia educational technology», etc. This indicates that the essence of ICT concepts, used in education is still not well established.

ICT of foreign languages implies, first and foremost, dialogue training, during which the subjects of the educational process interact. It can be organized using interactive learning technologies and approaches. The essence of foreign languages interactive learning is that the learning process takes place under the condition of constant, active interaction of all learning subjects (teachers and students). This is mutual learning (collective, group, collaborative) where the student and the teacher are equal subjects of learning.

Information and communication technologies of foreign language learning is the organization of foreign language communication of the study subjects which provides, according to the study purposes, learners' individual peculiarities, the most rational complex application of methods, techniques, means and forms of learning in order to achieve the preplanned level of communicative competence.

These learning technologies can be implemented in both traditional and innovative student learning processes using computeroriented learning tools and methods. Organizing the process of interpersonal communication in the process of traditional (non-computer) learning is a simple task (student surveys, discussions, seminars, lectures, round tables, etc.). The organization of a similar process during computer-oriented, in particular, distance learning is a problem that is currently being studied by many researchers (Ch. Davison, G. Jacobs, Th. Farrell, J. Richards, R. Gurevych, V. Kukharenko, and etc.).

Recently, more and more attention has been given to the development of computerbased learning technologies by increasing the level of their interactivity in the process of application in the educational process, which affects the quality of students' perception of educational material. Analysis of the scientists' work on the problem of providing computeroriented learning interactivity shows that its interactivity can be spoken only when the following characteristics are realized during students' educational and cognitive activity:

- non-linear access to educational information using hypertext technology;

- interpersonal communication;

- responsiveness of subject-subject (teacher $\leftrightarrow$ students, student $\leftrightarrow$ student) and subjectobject (student $\leftrightarrow$ computer- based learning tool) feedbacks; choice;

- providing students with the right of

- adaptation of the study system to the individual characteristics of students.

An important component of interactive learning technologies is the studying method. In 
modern foreign language learning methods, this notion is interpreted as a way to the stated goal, it means a way of orderly activity of the teacher and the student on the way to the set learning goals, that is, a way of interaction between the student and the teacher [7].

Thus, the studying interactive method is a way of collective interaction of the pedagogical process participants through conversation, dialogue, during which they interact with the purpose of mutual understanding, joint solving of educational tasks, development of learners' personal qualities.

The most common traditional methods for organizing interactive learning used during the foreign language studying and teaching process at a higher education institutions are: verbal methods - conversation, dialogue; visual methods - interactive demonstration; corporate training methods - work in pairs, work in small groups, carousel, etc.; collective and group studying methods - «situation analysis», «brainstorming", problem solving, etc.; situational studying methods - simulation games; discussion methods of studying discussion, debate, etc.; research methods project method, etc.

Computer-oriented teaching methods have emerged, the main purposes of their use in the process of a foreign language learning are:

1) development of attention, fantasy, imagination, observation, non-standard thinking, interest in learning;

2) formation of a multicultural personality;

3) fostering systematic, logical, critical and creative thinking, as well as efficiency, curiosity, cognitive independence and perseverance in achieving the goal;

4) activation of students' educational and cognitive activity;

5) filling of gaps in knowledge, skills in foreign languages;

6) development of self-learning, selfdevelopment and self-improvement skills;

7) forming the ability to think, create, independently acquire and learnknowledge, skills and abilities.

The teacher's choice of interactive computer-based teaching methods for foreign languages should be subject to the following requirements:

- focus on innovative, integrative, communicative and personal-activity principles of studying organization;

- taking into account the psychological characteristics of students, their readiness for self-study with the use of information technology tools;
- teachers' willingness to use interactive computer-based teaching methods in the educational process;

- the readiness of the higher education institution's information infrastructure for the introduction of interactive computer-based teaching methods into the educational process;

- consideration of environmental conditions (social, economic etc).

Let's look at some examples of innovative foreign language teaching technologies in the world. There are a number of foreign studies examining innovative practices against the background of internationalization changes in higher education.

First of all, it is said that ICT have expanded the reach of new language practices, only one «click"» gives access to the Englishspeaking community and an unlimited number of original text and media sources. Through various projects and programs, European citizens have emerged with new mobility opportunities, which take the form of academic exchanges, study tours, mobile language courses and more.

Thanks to the rapidly evolving information technology, students have the opportunity to communicate with people of all ages, cultures and social backgrounds. Most teaching and learning complexes have been based on «learning English as a lingua franca», without so-called binding to native speakers of countries where English is official de jure or de facto because the number of speakers for whom it is is foreign, far exceeding the number for whom it is native. Given the availability of synchronous and asynchronous interaction with individuals and groups from all over the world, teachers are no longer required to stimulate «fictional» activities (role-playing games, business games, imitations, etc.). Instead, their primary role is to organize real communication. Information technology brings to the audience of the participants of communication, or to put it more correctly, expands the educational audience to the size of the world.

However, the teacher needs much more tools to engage students in communication. One of them is the focus on the specific tasks and activities that underlie the communicativeactivity approach to learning foreign languages. The innovative nature of these foreign language lessons is that they are task oriented. No matter how traditional it may seem at first glance, activity-based learning is relatively new in teaching foreign languages in Ukraine. It is said that in the 1970s, foreign language teaching began to develop a theoretical and practical 
approach that gave impetus to task-based or activity-based learning.

From the early 1970s, when the communicative approach sounded authoritative in foreign language education, it went through several stages. In the first of these, major efforts were directed to the development of teaching methods aimed at developing communicative competence. As a consequence, there has been a shift in emphasis from grammatical structures to communicative functions. Subsequently, the deepening scientific interest attracted procedures for determining communicative needs and developing types of educational activities for Comparative and Educational Studies introduction of a communicative approach. Today, the communicative approach to foreign language learning is a combination of key principles that underlie learning.

Methodists G. Jacobs and Th. Farrell identify eight innovative changes in foreign language education caused by the paradigmatic changes outlined above [6]:

1) the autonomy of the learner, which is to give him the right to choose the content and process of learning;

2) the social nature of the learner, which is determined by the interaction of other participants in the learning process;

3) curriculum integration demonstrating that English is closely related to other subjects;

4) focus on value as the driving force of learning;

5) diversity based on awareness of different learning styles;

6) creative thinking skills that are considered necessary when using a foreign language outside of the classroom;

7) alternative assessment, which allows to determine the overall picture of the ability to use a foreign language;

8) teachers as students' partners in mutual learning.

So, this is a complete change in the role of the teacher, who is from the data carrier about peculiarities of grammatical, phonetic, lexical language levels is transformed into a communication facilitator in the process of common activities with students.

Conclusions and prospects for further research of the direction. Consequently, we considered some of the most important, in our opinion, conditions and ways of forming positive, stable students' educational activities. IC foreign language learning technologies are promising technologies because they define dialogue as a leading form of educational and cognitive interactive learning interaction with operational feedback and provide consideration of the basic methodological principles of foreign language communication and situationally thematic organization of learning.

Characteristic features of informationcommunication technologies of teaching foreign languages in higher education institutions are: activity, teamwork, communicative and situational character of educational activity; development in students of reflexive skills, attention, fantasy, imagination, observation, non-standard thinking; education of systematic, logical, critical and creative thinking, as well as efficiency, inquisitiveness, cognitive independence and perseverance in achievement of the goal.

\section{СПИСОК ДЖЕРЕЛ}

1. Blair, R. (1982). Innovative approaches to language teaching. New York: Newbury House.

2. Celce - Hurcia, H. (1991). Teaching English as a Second Foreign Language. Heinle L Heinle Publishers - Boston, Massachusetts.

3. Davison, Ch. (2009). Information Technology and Innovation in Language Education. Hong Kong: Hong Kong University Press.

4. Dudeney, G. (2008). How to Teach English with Technology. Pearson Longman.

5. Hartoyo (2008). Individual Differences in Computer-Assisted Language Learning. Semarang: Pelita Insani Semarang.

6. Jacobs, G., Farrell, Th. (2008). Paradigm shift: Understanding and implementing change in second language education. TESL-EJ.

7. Kriuchkov, H. (2004). The Bologna Process as a Harmonization of the European Higher Education System. Foreign languages in educational institutions.

\section{REFERENCES}

1. Blair, R. (1982). Innovatsiyni pidkhody do vykladannya movy. [Innovative approaches to language teaching]. New York.

2. Celce - Hurcia, H. (1991). Vykladannya anhliys'koyi movy yak druhoyi inozemnoyi movy. [Teaching English as a Second Foreign Language]. Boston.

3. Davison, Ch. (2009). Informatsiyni tekhnolohiyi ta innovatsiyi $v$ movniy osviti. [Information Technology and Innovation in Language Education]. Hong Kong.

4. Dudeney, G. (2008). ak vchyty anhliys'ku movu za dopomohoyu tekhnolohiy. [How to Teach English with Technology].

5. Hartoyo (2008). Indyvidual'ni vidminnosti $u$ vyvchenni movy za dopomohoyu komp"yutera. [Individual Differences in Computer-Assisted Language Learning].

6. Jacobs, G., Farrell, Th. (2008). Zmina 
paradyhmy: Rozuminnya ta vprovadzhennya zmin $u$ navchanni druhoyu movoyu. [Paradigm shift: Understanding and implementing change in second language education].

7. Kriuchkov, H. (2017). Bolons'kyy protses yak harmonizatsiya yevropeys'koyi systemy vyshchoyi osvity. Inozemni movy $v$ navchal'nykh zakladakh. [The Bologna Process as a Harmonization of the European Higher Education System. Foreign languages in educational institutions].

\section{ВІДОМОСТІ ПРО АВТОРІВ}

АНТОНІВСЬКА Марина Олександрівна викладач кафедри іноземної філології Київського національного університету культури і мистецтв.

Наукові інтереси: методика викладання іноземних мов у 3ВО, новітні парадигми у процесі викладання англійської мови у вищій школі, інтеркультурна комунікація.

\section{САРНОВСБКА Наталія Іванівна -} викладач кафедри іноземної філології Київського національного університету культури і мистецтв.

Наукові інтереси: теорія і методика викладання, комунікативна компетенція, інноваційні методи навчання.

\section{INFORMATION ABOUT THE AUTHOR}

ANTONIVSKA Maryna Oleksandrivna Lecturer at the Department of Foreign Philology, Kyiv National University of Culture and Arts.

Circle of scientific interests: methods of foreign languages teaching in Higher Educational Institutions, the latest paradigms in the process of teaching English in high school, intercultural communication.

SARNOVSKA Natalia Ivanivna - Lecturer at the Department of Foreign Philology, Kyiv National University of Culture and Arts.

Circle of scientific interests: the theory and methods of teaching, communicative competence and innovative teaching methods.

Стаття надійшла до редакиії 14.01.2020 p.

УДК 811.161.2'243:378.147

DOI: 10.36550/2415-7988-2020-1-188-179-184

ЛІПАТОВА Марина Валентинівна викладач кафедри історії, археології, інформаційної та архівної справи Центральноукраїнського національного технічного університету ORCID:https://orcid.org/0000-0002-6410-1762 e-mail: lipatovam@ukr.net

\section{ДО ПИТАННЯ НАВЧАННЯ ЛЕКСИКИ УКРАЇНСЬКОЇ МОВИ СТУДЕНТІВ-ІНОЗЕМЦІВ НА ПОЧАТКОВОМУ ЕТАПІ}

\begin{abstract}
Постановка та обгрунтування актуальності проблеми. Україна володіє значним освітнім потенціалом і $€$ активним учасником міжнародного ринку освітніх послуг. Важливим напрямком інтеграції української системи освіти в міжнародний освітній простір $€$ навчання іноземців у закладах вищої освіти України й вдосконалення системи підготовки фахівців для зарубіжних країн 3 метою зміцнення та розвитку міжнародних зв'язків. Тисячі іноземних студентів здобувають вищу освіту українською мовою.

Мета мовної підготовки іноземних студентів полягає у забезпеченні їхніх комунікативних потреб у різних сферах спілкування: науковій (для отримання якісної підготовки за обраним фахом), суспільнополітичній і соціально-культурній (для належної адаптації та повноцінного орієнтування в новому соціальнокультурному середовищі), побутовій (для задоволення потреб повсякденного життя), а
\end{abstract}

також для виховання гармонійної особистості, що здатна до міжкультурного діалогу [4].

Методика викладання української мови як іноземної - молода наука. Викладання української мови іноземним студентам має значну кількість невирішених проблем у навчанні фонетики, лексики, граматики, різних видів мовленнєвої діяльності, існує недостатня розробленість методики викладання української мови як іноземної. Тому питання методики викладання української мови іноземним студентам $\epsilon$ наразі дуже актуальним.

Велика увага науковців та викладачів мовної підготовки приділяється удосконаленню форм і методів викладання української мови як іноземної, пошуку шляхів підвищення пізнавального інтересу студентів до вивчення мови.

Аналіз останніх досліджень та публікацій. Першими грунтовними дослідженнями, важливими для розвитку 